\title{
An Approach to Physical Exercise Model Using Play- Way Methods Through Futsal Sports for Junior High School Students
}

\author{
Muhtar Asshagab*, Widiastuti Widiastuti, Firmansyah \\ Dlis \\ Universitas Negeri Jakarta \\ Jakarta, Indonesia \\ *masshagab@gmail.com
}

\author{
Sandey Tantra Paramitha \\ Fakultas Pendidikan Olahraga dan Kesehatan \\ Universitas Pendidikan Indonesia \\ Bandung, Indonesia
}

\begin{abstract}
The main aim of this research was to develop a physical exercise model by using play-way methods through futsal sports for junior high school students. The specific objectives of this study were: 1) To find out how a physical exercise model using play-way methods through futsal sports for junior high school students; and 2) To find out if a physical exercise model using play-way methods through futsal sports is effective for junior high school students. In the design of this study, the researchers referred to development model of Research and Development (R\&D) of Borg and Gall. The results of the model is not only the development of an existing product but also to explore knowledge or answers to practical problems. Of the ten steps that exist in the model, the researchers made some adjustments as needed. The results of this study, conducted through a series of expert evaluations, field trials, and discussion of research results, indicate that this product is suitable for junior high school students. The results of the effectiveness test show that the mean value for the physical exercise group using play-way model is $\mathbf{4 2 8 . 2 1}$ and the mean value for conventional group is 335.55 with $t$-test value is 3.447 . Therefore, the physical exercise model using play-way methods for junior high school students who develop talents and interests in extracurricular activities of futsal sports is effective to improve their physical abilities and is overall worthy of use.
\end{abstract}

Keywords: exercise model, play-way method, physical condition

\section{INTRODUCTION}

The game of futsal is much influenced by the development of football [1]. This can be seen from the characteristics of the game of futsal which is not much different from the sport of soccer [2]. Nevertheless, there are basic rules that have been agreed to in this game that are clearly different from the rules of the game in football [3].

Futsal has characteristics or style of play that gives all players the opportunity to attack openly, so that futsal players are required to have good physical fitness [4]. Physical fitness in the form of excellent physical fitness to support the appearance of a player [5]. Physical preparation is important in the preparation period of a team to achieve optimal performance [6]. Through physical training, the player's poor condition will improve [7].
There are differences in physical training models using conventional and unconventional training models as shown in Figure 1 below:

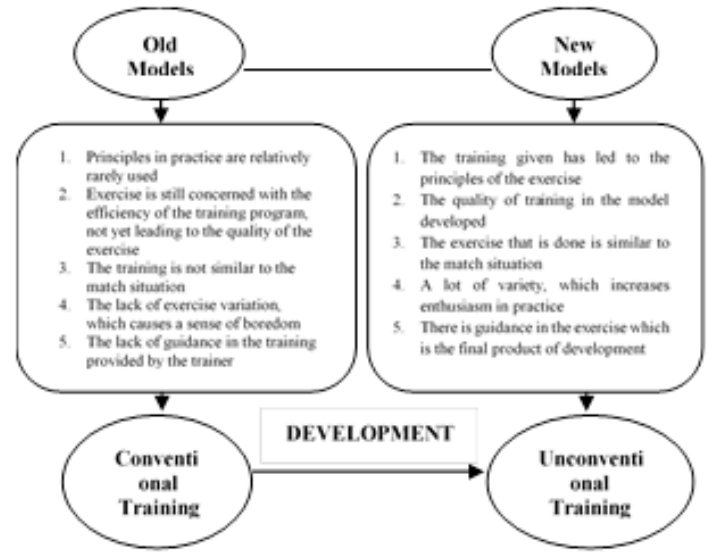

Fig. 1. Difference between the old model and new model.

Based on the background above, the researchers was highly interested in conducting this study with a main question, "how is the physical training model with the method of playing through futsal in junior high school students?"

\section{METHOD}

Researchers referred to the Research and Development (R\&D) development model of Borg and Gall [8] with the following steps: (1) Carry out research and information gathering (literature review, class observations, and preparation of reports on the subject matter; (2) Plan (defining skills, formulating goals, determining the order of teaching, and small-scale trials); (3) Develop initial product forms (preparation of training materials/models, and evaluation equipment); (4) Use the initial field test (small group test); (5) Revise the main product (in accordance with the recommendations of the initial field test results); (6) Carry out the main field test (large group test); (7) Conduct product revisions (based on suggestions and main field trials); (8) Field test (effectiveness test); (9) Revision of the final product; (10) Product Dissemination and Implementation. 
In general, the flow of research and development of the "Research and Development" (R\&D) model from Borg and Gall [8] is depicted, as shown below:

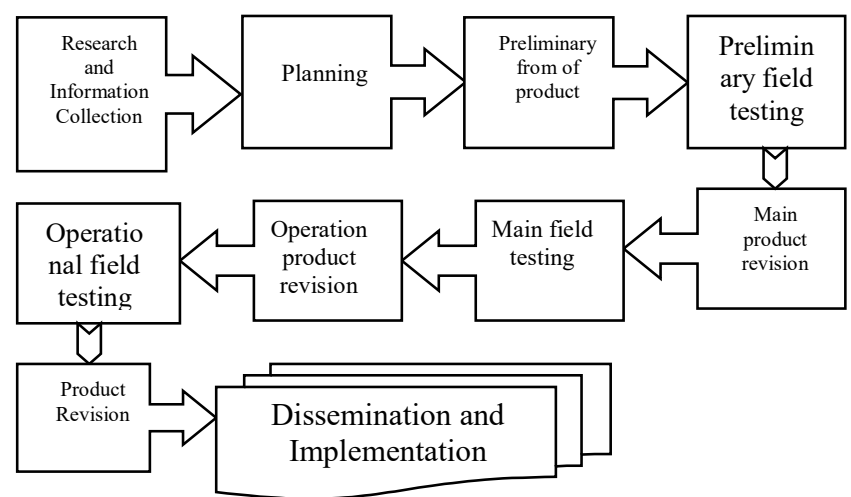

Fig. 2. Research and development phase (source: education research [8]).

\section{RESULTS}

\section{A. Requirements Analysis}

Data collection techniques in the needs analysis are based on the results of interviews, observations and questionnaires (Table 1).

TABLE I. NEEDS ANALYSIS

\begin{tabular}{|c|c|}
\hline Method & Data Conclusion \\
\hline Observation & $\begin{array}{l}\text { That the training undertaken so far does not or does not } \\
\text { pay enough attention to the principles contained in the } \\
\text { exercise. } \\
\text { Exercise is still concerned with the efficiency of the } \\
\text { training program, not yet leading to the quality of the } \\
\text { training. } \\
\text { The exercises are still conventional in nature, as } \\
\text { evidenced by the lack of variation that is done while the } \\
\text { exercise is taking place. }\end{array}$ \\
\hline Interview & $\begin{array}{l}\text { The informant stated that there was no manual to train } \\
\text { physically, especially futsal. } \\
\text { Another informant stated that it was difficult to find } \\
\text { training methods used in adding training variations. } \\
\text { Strengthened by the statement, really need a model of } \\
\text { physical exercise with the method of playing through } \\
\text { futsal. }\end{array}$ \\
\hline Questionnaire & $\begin{array}{l}\text { The results of the questionnaire-questionnaire obtained } \\
\text { from players / students as research subjects showed a } \\
\text { percentage of } 65.25 \% \text { (sixty five point twenty five } \\
\text { percent) } \\
\text { From the results of the questionnaire-questionnaire } \\
\text { distribution can be interpreted that the development of } \\
\text { physical training models with the method of playing } \\
\text { through futsal sports agreed to be developed. }\end{array}$ \\
\hline
\end{tabular}

The results of the needs analysis can be stated that the presence of a physical training model with the method of playing through futsal sports becomes something that needs to be developed in specific physical training for junior high school players / students who follow the development of students' talents and interests in the extracurricular activities.

\section{B. Initial Draft Concept (Initial Model)}

Fundamental principles in training include: 1) The principle of overload; 2) The principle of overall development (progressive); 3) The principle of specificity (specialization); 4) The principle of individual (individualization); 5) The principle of variation. By referring to this, an initial draft model was made. The purpose of making the initial draft concept is to find a picture of the developed model design (Table 2).

TABLE II. DRAFT PRELIMINARY CONCEPTS

\begin{tabular}{|c|c|c|c|c|}
\hline Needs Physic & $\begin{array}{l}\text { Principle of } \\
\text { Training }\end{array}$ & \multicolumn{3}{|c|}{$\begin{array}{l}\text { Physical Training with Play } \\
\text { Method }\end{array}$} \\
\hline 1. Endurance & 1. Overload & Functional & Conditional & Tactic \\
\hline 2. Strength & 2. Progressive & $\begin{array}{l}\text { Model- } \\
\text { M1 }\end{array}$ & $\begin{array}{l}\text { Model- } \\
\text { M12 }\end{array}$ & $\begin{array}{l}\text { Model- } \\
\text { M23 }\end{array}$ \\
\hline 3. Speed & 3. Specialization & $\begin{array}{l}\text { Model- } \\
\text { M2 }\end{array}$ & $\begin{array}{l}\text { Model- } \\
\text { M13 }\end{array}$ & $\begin{array}{l}\text { Model- } \\
\text { M24 }\end{array}$ \\
\hline 4. Agility & $\begin{array}{l}4 . \\
\text { Individualization }\end{array}$ & $\begin{array}{l}\text { Model- } \\
\text { M3 }\end{array}$ & $\begin{array}{l}\text { Model- } \\
\text { M14 }\end{array}$ & $\begin{array}{l}\text { Model- } \\
\text { M25 }\end{array}$ \\
\hline \multirow[t]{8}{*}{$\begin{array}{l}5 . \\
\text { Coordination }\end{array}$} & 5. Variation & $\begin{array}{l}\text { Model- } \\
\text { M4 }\end{array}$ & $\begin{array}{l}\text { Model- } \\
\text { M15 }\end{array}$ & $\begin{array}{l}\text { Model- } \\
\text { M26 }\end{array}$ \\
\hline & & $\begin{array}{l}\text { Model- } \\
\text { M5 }\end{array}$ & $\begin{array}{l}\text { Model- } \\
\text { M16 }\end{array}$ & $\begin{array}{l}\text { Model- } \\
\text { M27 }\end{array}$ \\
\hline & & $\begin{array}{l}\text { Model- } \\
\text { M6 }\end{array}$ & $\begin{array}{l}\text { Model- } \\
\text { M17 }\end{array}$ & $\begin{array}{l}\text { Model- } \\
\text { M28 }\end{array}$ \\
\hline & & $\begin{array}{l}\text { Model- } \\
\text { M7 }\end{array}$ & $\begin{array}{l}\text { Model- } \\
\text { M18 }\end{array}$ & \\
\hline & & $\begin{array}{l}\text { Model- } \\
\text { M8 }\end{array}$ & $\begin{array}{l}\text { Model- } \\
\text { M19 }\end{array}$ & \\
\hline & & $\begin{array}{l}\text { Model- } \\
\text { M9 }\end{array}$ & $\begin{array}{l}\text { Model- } \\
\text { M20 }\end{array}$ & \\
\hline & & $\begin{array}{l}\text { Model- } \\
\text { M10 }\end{array}$ & $\begin{array}{l}\text { Model- } \\
\text { M21 }\end{array}$ & \\
\hline & & $\begin{array}{l}\text { Model- } \\
\text { M11 }\end{array}$ & $\begin{array}{l}\text { Model- } \\
\text { M22 }\end{array}$ & \\
\hline Total Number & odel Variations & 11 & 11 & 6 \\
\hline
\end{tabular}

The initial draft concept is made as much as possible by basing on the results of the needs analysis and also theoretical studies. So with these results the draft concept of the initial model contained 28 (twenty eight) with a variety of physical exercise models using the method of playing through futsal.

\section{Feasibility Model}

The feasibility test of the model involves 7 (seven) experts who have competencies in their respective fields, namely 2 (two) sports coaching methodology experts, 3 (three) futsal experts, and 2 (two) media experts. The purpose of the feasibility test is intended to obtain validation results from the developed model (Figure 3).

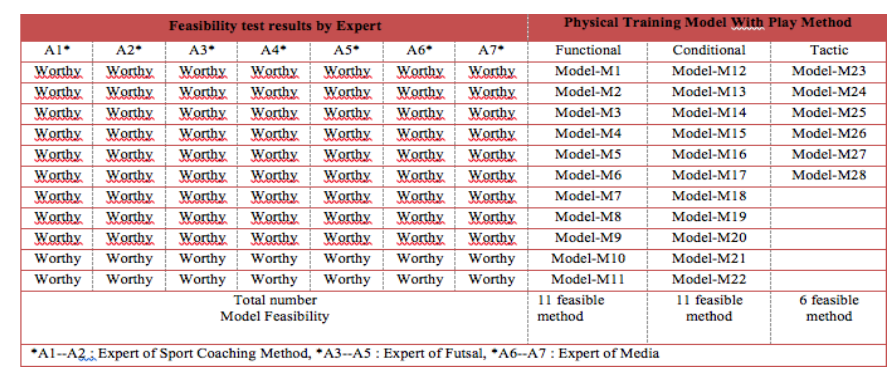

Fig. 3. Model feasibility test results. 
The table above is the acquisition of the feasibility test results obtained based on the results of data collection from each expert. Based on the results in the table above, it can be stated that the physical training model with the playing method of junior high school students, who develop students' talents and interests in extracurricular activities in the form of futsal, gets a decent title. After revisions or improvements based on suggestions, responses and input from experts, several input results are obtained (Figure 4).

\begin{tabular}{|c|c|c|c|}
\hline No. & Model & $\begin{array}{l}\text { Expert } \\
\text { Revition }\end{array}$ & Note \\
\hline 1 & $\begin{array}{l}\text { - Model-M1 } \\
\text { - Model-M4 } \\
\text { - Model-M5 } \\
\text { - Model-M6 } \\
\text { - Model-M13 } \\
\text { - Model-M15 }\end{array}$ & $\begin{array}{c}\text { Coaching } \\
\text { Methodology }\end{array}$ & $\begin{array}{l}\text { 1. Forms of training need to have some } \\
\text { replaced } \\
\text { 2. Some models do not reflect the } \\
\text { characteristics of physical exercise } \\
\text { with appropriate playing methods. }\end{array}$ \\
\hline 2 & $\begin{array}{l}\text { - Model-M1 } \\
\text { - Model-M2 } \\
\text { - Model-M3 } \\
\text { - Model-M7 } \\
\text { - Model-M8 } \\
\text { - Model-M9 } \\
\text { - Model-M11 } \\
\text { - Model-M12 } \\
\text { - Model-M17 } \\
\text { - Model-M18 } \\
\text { - Model-M19 } \\
\text { - Model-M20 } \\
\text { - Model-M21 } \\
\text { - Model-M27 } \\
\text { - Model-M28 }\end{array}$ & $\begin{array}{l}\text { Soccer and } \\
\text { Futsal }\end{array}$ & $\begin{array}{l}\text { 1. Additional cones for place and } \\
\text { direction of movement } \\
\text { 2. The exercise follows the sequence } \\
\text { number in the picture } \\
\text { 3. Implementation instructions must be } \\
\text { detailed and detailed so that they are } \\
\text { easy to understand Arrange and sort } \\
\text { exercises from simple to complex } \\
\text { 4. The plaxing area and the distance } \\
\text { between each player must be clearly } \\
\text { sized } \\
\text { 5. The level of difficulty adjusts to the } \\
\text { growth and development of junior } \\
\text { high school age children }\end{array}$ \\
\hline 3 & All Model & Media & $\begin{array}{l}\text { 1. Clarity of writing needs to be arranged } \\
\text { according to the sentence and font size } \\
\text { 2. Winning writings need improvement } \\
\text { related to the content and description } \\
\text { of the material and } \\
\text { 3. Language suitability Image } \\
\text { compatibility is quite appropriate }\end{array}$ \\
\hline
\end{tabular}

Fig. 4. Model revision results by experts or experts.

The revised results are then used as a foothold in improving the model. After improving the training model by following the directions that have been delivered by experts, the next step is to try out a model that has been feasible to players / students who develop students' talents and interests in extracurricular activities in the form of futsal [9]. This trial is conducted on small groups and large groups.

1) Small Trial Results: From the table V, it can be seen that the results of small group trials of all models can be implemented by players / students who develop students' talents and interests in futsal as extracurricular activities. This means that the developed model can be fulfilled. At the same time focus group discussions (FGD) are also carried out involving practitioners, coaches or futsal trainers, this involvement is very important in order to evaluate the product models that have been tested on small groups. That is why the FGD becomes a part of the benchmark for the models being developed. Besides that, it also functions to look deeper, to what extent the model tested can be achieved well.

\begin{tabular}{|c|c|c|c|}
\hline Functional & Conditional & Tactic & Noted \\
\hline Model 1 & Model 12 & Model 23 & \\
\hline Model 2 & Model 13 & Model 24 & \\
\hline Model 3 & Model 14 & Model 25 & \\
\hline Model 4 & Model 15 & Model 26 & \multirow{2}{*}{ Can be } \\
\hline Model 5 & Model 16 & Model 27 & Done \\
\hline Model 6 & Model 17 & Model 28 & \\
\hline Model 7 & Model 18 & & \\
\hline Model 8 & Model 19 & & \\
\hline Model 9 & Model 20 & & \\
\hline Model 10 & Model 21 & & \\
\hline Model 11 & Model 22 & & \\
\hline & & & \\
\hline & & & \\
\hline & & & \\
\hline
\end{tabular}

Fig. 5. Small trial results.

From the FGD results, it can be stated that the training model can be applied well, even though there are obstacles, but it does not become a significant obstacle. The results can be narrated in the form of presentations as stated in the statement, which are as follows: "... Training with a model or method of play can already be used, but players / students who should practice futsal should try it first, considering that the training model items are quite varied, which tends to players / students remembering again between one series to another. Overall it is effective to apply and quite acceptable to them. (CL / 01 / FGD / 01)."

By paying attention to the results of the FGDs that have been described previously, the first thing that can be understood is that the standard operating procedures (SOP) need to be clarified. Both players / students who practice futsal before doing the physical training model are first welcome to try the exercise model. Such input is very useful for improvement, before it is implemented in large trials. Noting this statement, the SOPs were improved, so that during the large trial the incident would not be repeated. After the improvement, it can be concluded that the physical exercise model with the play method can be tested on a larger group.

2) Large Group Trial Results: In large group trials or trials on a broader scale referred to in this case the physical training model product with the method of playing back to be tested again involving 30 (thirty) players / students who practice futsal. This large group trial is also based on the results of small group trials in the form of suggestions, input, or responses from the FGD results. That way in large group trials there has been an improvement from the model developed.

\begin{tabular}{|c|c|c|c|}
\hline Functional & Conditional & Tactic & \multirow{2}{*}{ Noted } \\
\hline Model 1 & Model 12 & Model 23 & \\
\cline { 1 - 3 } Model 2 & Model 13 & Model 24 & \\
\cline { 1 - 2 } Model 3 & Model 14 & Model 25 & \\
\hline Model 4 & Model 15 & Model 26 & \multirow{2}{*}{$\begin{array}{c}\text { Can be } \\
\text { Done }\end{array}$} \\
\hline Model 5 & Model 16 & Model 27 & \\
\hline Model 6 & Model 17 & Model 28 & \\
\hline Model 7 & Model 18 & & \\
\hline Model 8 & Model 19 & & \\
\hline Model 9 & Model 20 & & \\
\hline Model 10 & Model 21 & & \\
\hline Model 11 & Model 22 & & \\
\hline & & & \\
\hline
\end{tabular}

Fig. 6. Large trial results.

From the above table, it has been found that in the large group trials the physical training model with playing methods on junior high school students, which develops students' talents and interests in extracurricular activities in the form of futsal is fulfilled when applied in the field. In other words, the physical exercise model has been achieved in accordance with the initial 
goal in development, namely developing a physical exercise model with the play method. In here, the researchers also conducted FGD to gain feedback, suggestions or also input from the developed training model.

The results of FGD on large group trials did not find any prominent deficiencies. This indicates that the model developed can be realized well, according to the results of the FGD as stated, as below: "... the physical training model is as expected. This training model is also very good for developing the physical condition of players / students who practice futsal. From the equipment side, it is also suggested to create clear SOP. The use of the model developed in physical training is no doubt its validity (CL / 02 / FGD / 02)." Based on the above sentence, the development of physical training models in large group trials does not need revision. In other words, the model has met the eligibility standard, both in terms of the methodology of sports coaching and in terms of coaching especially the futsal sports.

The results of the FGD discussion can also be stated that the training model developed is quite effective and there is no doubt about its validity. This can reinforce that the ability of the physical elements needed by still paying attention to the principles when training, it can be accomplished by a physical training model with the method of playing on junior high school students, which develops students' talents and interests in futsal extracurricular activities fulfilled when applied in the field and also in the large group trial process, with this model there are no significant obstacles.

\section{Model Effectiveness}

The design used in this effectiveness test uses a randomized control group pretest - posttest design [10]. The design is a pure experimental design with the characteristics of the control group samples taken randomly from certain populations. The purpose and objectives of the different test (t-test) is to see the effectiveness of the treatment given. In this test, the researchers use quantitative data by looking at the results between pretestpostest and results between groups (Figure 7).

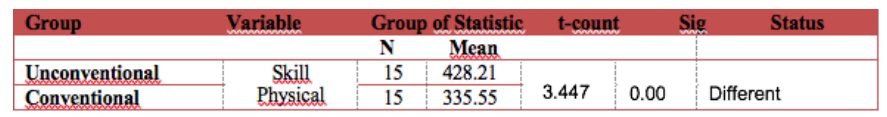

Fig. 7. Test results between group differences.

From the acquisition of the above table results from each group, it can be seen the mean value for the physical exercise group with the play method (unconventional) of 428.21 and the conventional group value of 335.55 , the t-count value of 3,447 compared to conventional training. This further confirms that the physical training model with the method of playing (unconventional) is more able to stimulate the physical abilities of students / futsal players effectively and comprehensively. Thus, the physical training model with the method of playing in junior high school students, who develop students' talents and interests in futsal extracurricular activities, with these varied models is no doubt in implementation in the field [11].

\section{DISCUSSION}

The results of the theoretical study of physical exercise to be applied using the method of playing unconventional. The use of this method was decided after conducting in-depth theoretical studies that physical training using the method of playing through futsal is considered effective in developing physical abilities in junior high school students, which develop students' talents and interests in futsal extracurricular activities, because all elements of physical condition can be trained simultaneously. Besides that, with the availability of time in training which tends to be very limited, it becomes a distinct advantage for the coach and the player, because with unconventional playing methods other forms of training can be integrated. This is why unconventional playing methods need to be developed as a way to overcome this problem.

The model of physical training using the unconventional playing method in this development is especially aimed at junior high school students, who develop students' talents and interests in extracurricular activities through futsal. This training model is indeed designed in such a way as to help in developing their physical abilities [12]. Correspondingly, this training model can also help coaches in designing physical training for futsal players. The existence of this model can also enrich the coach's reference in providing variations in physical training for futsal players. However, the results of the development of this training model need to pay attention to the facilities and infrastructure used, this is considering that almost all forms of training use the help of tools such as cones, balls, and other auxiliary equipment as a medium in implementing the physical exercise.

The resulting model also has several supporting factors in applying physical exercise. The supporting factor is the facilities and infrastructure used in implementing the training model is quite complete, so that it can be easier to apply physical training models. This is a special note for every club and futsal school that if applying physical training using unconventional playing methods it is necessary to consider the facilities and infrastructure used. Besides that, this discussion also presents the strengths and weaknesses of the resulting model. The strength of this model lies in increasing physical abilities that can be done together, this is a distinct advantage for the trainer.

Sometimes, the availability of time in the training process is quite short. So that this model is considered to be very effective in developing components of physical conditions simultaneously, this is because in the training process all physical elements can be trained on each item that has been determined. While the weak point in this model is the tendency of players / students to rush in doing the exercise. This can be seen from the psychological side with the number of good training model items from functional, conditional to tactical training exercises enabling them to want as soon as possible to complete the physical training. The role of the coach in this case becomes important to realize it, intensive communication with players, which develops the talent and interest of players / students in futsal extracurricular activities is something that needs to be done in order to realize the stated training objectives. 
[3] R. Hay, "Football's First Free Kick: Demography and the Media - How and Why Australia Got a Game of Its Own," The International Journal of the History of Sport, vol. 33(3), pp. 289-305, 2016.

All in all, the resulting training model has become a solution to the problems that occur in the field. This training model has been systematically carried out in depth, so that it can be scientifically justified. This model is also quite proven to be able to increase the physical abilities of futsal players. This can be one way for coaches if they want to develop the physical abilities of futsal players, the selection of physical training models with unconventional playing methods is the right thing to do.

\section{CONCLUSIONS}

The results showed that there were significant differences before and after the treatment of physical exercises using play methods by utilizing the 3 (three) steps of the framework, namely functional, conditional, and tactical game exercises through futsal. So it can be stated that the product is truly in accordance with the needs that exist in the field and effectively used to improve the results of futsal physical training for junior high school age children.

\section{REFERENCES}

[1] L. O. Bezerra, F. Sabino, V. H. Germano Ferreira, and F. V. Vasconcellos, "Comparative between football 7-a-side and football 11-aside: quantity and frequency of actions performed by goalkeepers," Revista Brasileira de Futsal e Futebol, vol. 10(38), pp. 300-307, 2018.

[2] M. A. Syakur, , Badruzaman, and S. T. Paramitha, "Pengembangan Alat Bantu Latihan Pelontar Bola Futsal Berbasis Mikrokontroler dengan Menggunakan Software Pemograman Arduino," J. Terap. Ilmu Keolahragaan, vol. 2(1), pp. 29-32, 2017.

[4] N. Naser, A. Ali, and P. Macadam, "Physical and physiological demands of futsal," Journal of Exercise Science \& Fitness, vol. 15(2), pp.76-80, 2017.

[5] M.D. Kaos, M.R. Beauchamp, S. Bursick, A.E. Latimer-Cheung, H. Hernandez, D.E. Warburton, C. Yao, Z. Ye, T.N. Graham, and R.E. Rhodes, "Efficacy of online multi-player versus single-player exergames on adherence behaviors among children: A nonrandomized control trial," Annals of Behavioral Medicine, vol. 52(10), pp. 878-889, 2018.

[6] G. Raiola and T. D'isanto, "Assessment of periodization training in soccer," Journal of Human Sport and Exercise, vol. 11(1), pp. S267S278, 2016.

[7] C. Luna-Paredes, "Physical Activity and Exercise in Children with Chronic Pulmonary Diseases," 2018.

[8] W. R. Gall, M. D., Gall, J. P., \& Borg, "I dentifying a Research Problem and Question , and Searching," Educational research: An introduction, pp. 21-42, 2006.

[9] A. Junge, and J. Dvorak, "Injury risk of playing football in Futsal World Cups,” Br J Sports Med, vol. 44(15), pp. 1089-1092, 2010.

[10] A. Veloo, R. Md-Ali, and S. Chairany, "Using cooperative teams-gametournament in 11 religious school to improve mathematics understanding and communication," Malaysian Journal of Learning and Instruction, vol. 13(2), pp.97-123, 2016.

[11] S. Schulz, R. Stegwee, and C. Chronaki, "Standards in Healthcare Data," In Fundamentals of Clinical Data Science, pp. 19-36, 2019.

[12] J. Dattilo, "An Education Model to Promote Inclusive Leisure Services," Journal of Park and Recreation Administration, vol. 36(2), 2018. 